BIOMEDICAL AND BIOSOCIAL ANTHROPOLOGY
$\begin{gathered}\text { Official Journal of the International Academy } \\ \text { of Integrative Anthropology } \\ \text { journal homepage: http://bba-journal.com }\end{gathered}$

\title{
The effect of hyperhomocysteinemia on the patterns of electron microscopic changes in the liver of adult rats
}

Halahan Yu. V. ${ }^{1}$, Maievskyi O. Ye. ${ }^{2}$, Guminskyi Yu. Yo. ${ }^{1}$, Korol A. P. ${ }^{1}$

${ }^{1}$ National Pirogov Memorial Medical University, Vinnytsya, Ukraine

${ }^{2}$ Taras Shevchenko National University of Kyiv, Kyiv, Ukraine

\section{ARTICLE INFO}

Received: 10 June, 2019

Accepted: 14 July, 2019

UDC: $616-001.17: 615.451 .3$

CORRESPONDING AUTHOR

e-mail: Julia1301@ukr.net

Halahan Yu. V
One of the important tasks of modern science is to find biochemical markers that would be able to reflect the risks of development and the nature of the course of various diseases, as well as to predict their possible consequences. In recent years, a significant number of compounds that can affect the biochemical profile of the organism have been identified. Homocysteine - a product of methionine metabolism, belongs to one of these markers, and the effects of its influence on the structure and function of various organs are being actively studied by modern researchers. The aim of the study is to find the patterns of electron microscopic changes in the liver structure of adult rats with hyperhomocysteinemia. The experimental study was performed on 22 white nonlinear mature male rats, which were divided into a control group and an experimental group. A model of persistent hyperhomocysteinemia was created by administering to rats of experimental group thiolactone homocysteine at a dose of $200 \mathrm{mg} / \mathrm{kg}$ body weight intragastrically for 60 days. The study of ultrastructural changes in the liver of rats was performed using an electron microscope PEM-125K. In adult rats with experimental hyperhomocysteinemia at the ultrastructural level, dystrophic and destructive changes in hepatocytes, endotheliocytes in the walls of sinusoids and Kupffer cells were found. These changes were more pronounced than in young rats with experimental hyperhomocysteinemia. Revealed structural changes in decompensation (depletion) of mitochondria - fewer number of cristae and enlightened matrix. In contrast to young rats, adult rats with hyperhomocysteinemia in the perisinusoidal spaces showed elongated Ito cells, a significant proportion of the cytoplasm is occupied by the Golgi complex and granular endoplasmic reticulum tanks, indicating protein synthesis for export. In Ito cells, the content of fat droplets, which are located on opposite poles of cells, is reduced. This morphological picture manifests the transformation of Ito cells into fibroblasts.

Keywords: adult rats, liver, hyperhomocysteinemia, Kupffer cells, Ito cells.

\section{Introduction}

Homocysteine $(\mathrm{HC})$ is a sulfur-containing non-protein amino acid, a product of methionine metabolism. Within the normal concentration $(5-15 \mu \mathrm{mol} / \mathrm{l})$ it is important for the vital functions of the organism, but in case of excessive accumulation it creates preconditions for the development of oxidative stress, cell apoptosis, atherosclerosis, thrombosis, etc. $\mathrm{HC}$ is formed in the liver during methionine metabolism. Its utilization is carried out due to transulfation and remethylation reactions. The latter require vitamins B6, B12 and folic acid. Deficiency of these vitamins in the body can cause hyperhomocysteinemia $(\mathrm{HHC})$. In addition, $\mathrm{HHC}$ occurs in the case of congenital enzymopathy, smoking, alcohol consumption, long-term use of certain drugs, impaired renal function, liver [1, 12, 20].

$\mathrm{HC}$ has been shown to damage the vascular wall endothelium by activating mediators of inflammation and cell proliferation. It also increases the activity of histone acetylation processes $\mathrm{H} 3, \mathrm{H} 4$, reducing the expression of the CpG gene, which ultimately leads to conformational changes in chromatin and inhibition of the transcription process. One of the mechanisms of toxic effects of $\mathrm{HC}$ on the body is its ability to generate reactive oxygen species $[2,17]$. Because it contains an active thiol group, it is easily oxidized in the presence of oxygen and metal ions, causing the formation of active acid radicals - superoxide anion radical, hydrogen peroxide and hydroxyl radical. Therefore, 
elevated levels of $\mathrm{HC}$ can cause oxidative stress. This process is due to the inhibition of transcription, translation and catalytic activity of superoxide dismutase and glutathione peroxidase. Increasing the level of the above radicals ultimately leads to a direct cytotoxic effect on endothelial cells of the vascular wall. It should be noted that the oxidation process is also subject to LDL, while stimulating the processes of atherogenesis. In the walls of blood vessels $\mathrm{HC}$ reduces the bioavailability of nitric oxide for cells, so with a significant increase there is a violation of dilatation of the vascular wall $[4,5,7,8]$.

The negative effect of $\mathrm{HC}$ on blood clotting processes is proved. In particular, it causes resistance of factor $V$ to the action of activated protein $\mathrm{C}$. In addition, it blocks the interaction of thrombomodulin with thrombin and the binding of antithrombin III to heparan sulfate on the surface of endothelial cells [18].

At present, $\mathrm{HHC}$ has been associated with Alzheimer's disease, myocardial infarction, heart and kidney failure, atherosclerosis, stroke, non-alcoholic fatty liver disease $[3,10,21]$. The effect of $\mathrm{HC}$ on the structure of the liver is still insufficiently studied and requires more careful and indepth study. The reason for the increased attention of scientists to the peculiarities of morphological changes of the liver under the conditions of $\mathrm{HHC}$ is the fact of its participation in the main processes of metabolism of this amino acid. The obtained results can be used to develop methods to prevent the development of negative changes in hepatocytes and effectively treat their possible consequences.

The purpose of this study is to study the patterns of electron microscopic changes in the liver structure of adult rats with $\mathrm{HHC}$.

\section{Materials and methods}

The experiments were performed on 22 white nonlinear mature (6-8 months) male rats, which were divided into control and experimental groups. A model of persistent hyperhomocysteinemia was created by intragastric administration for 60 days to rats of the experimental group of thiolactone $\mathrm{HC}$ at a dose of $200 \mathrm{mg} / \mathrm{kg}$ body weight. Animals were removed from the experiment by decapitation under thiopental anesthesia.

Committee on Bioethics of National Pirogov Memorial Medical University, Vinnytsya found that the experimental study was conducted considering the recommendations of the European Commission for medical and biological research using animals, medical recommendations of the State Pharmacological Center of the Ministry of Health of Ukraine and "Rules for clinical safety assessment of pharmacological agents (GLP)."

For morphological examination, pieces of liver $0.5-1$ $\mathrm{mm}$ in size were taken and fixed in a $2.5 \%$ solution of glutaraldehyde with an active reaction medium $\mathrm{pH}$ 7.2-7.4, prepared on phosphate buffer. Next, the material was postfixed in a $1 \%$ solution of osmium tetroxide according to Caulfield. Dehydrated in alcohols of increasing concentration and acetone [6]. The material was poured into a mixture of epon-araldite. Semi-thin sections were made from the obtained blocks, which were stained with toluidine blue and Hyatt. After aiming at semi-thin sections, ultrathin sections were made on LKB III (Sweden) and Reihart (Austria) ultratomes, which were contrasted with $2 \%$ uranyl acetate solution and lead citrate. The preparations were examined and photographed under an electron microscope PEM-125K.

\section{Results}

In the experimental $\mathrm{HHC}$ in the cytoplasm of hepatocytes of adult rats, the channels of the endoplasmic reticulum and the tank of the Golgi complexes were expanded. Mitochondria are swollen, cristae are destructively altered, the matrix is electronically transparent. The membranes of some mitochondria are not continuous. Reduced content of glycogen granules and increased number of fat droplets in the cytoplasm, the latter are much larger in size than those in mature intact rats. Plasmolemma of hepatocytes is not homogeneous, focal with signs of edema. The lumens of the bile ducts are dilated. Autophagosomes were detected in the cytoplasm of some hepatocytes. The kernels had scalloped shapes, and chromatin was condensed in them. The karyoplasm is enlightened, the number of nucleoli is greater than in intact adult rats (Fig. 1, 2).

In contrast to young rats, in adult rats elongated Ito cells were found in the perisinusoidal spaces, a significant proportion of the cytoplasm is occupied by the Golgi complex and the granular endoplasmic reticulum, which indicated protein synthesis for export. The number of other organelles is smaller than that of intact mature rats. A small number of free ribosomes and polysomes, single mitochondria and

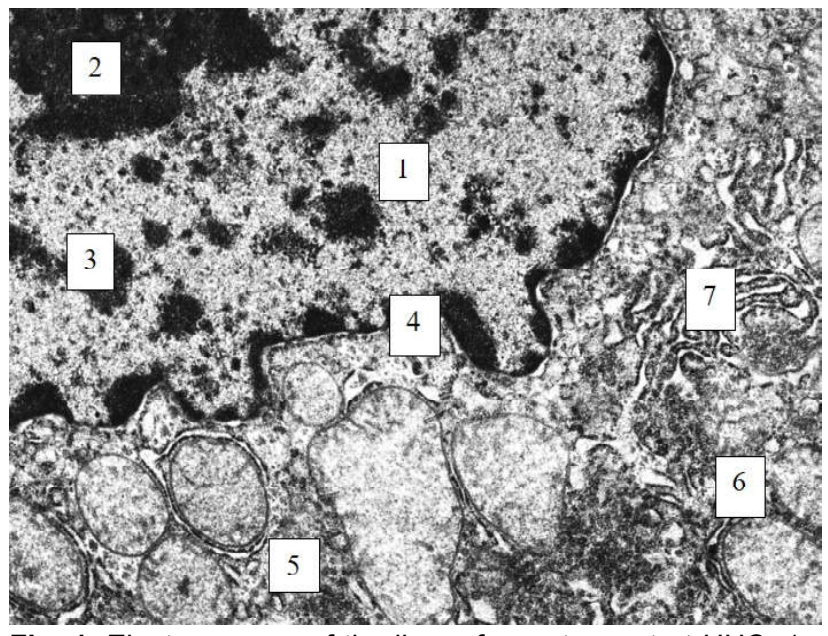

Fig. 1. Electronogram of the liver of a mature rat at HHC: 1 hepatocyte nucleus; 2 - nucleolus; 3 - condensed chromatin, in the central parts of the nuclei; 4 - intussusception of karyolemma; 5 cytoplasm of the hepatocyte; 6 - matrix edema and destruction of cristae in the mitochondria; 7 - expanded tanks of the granular endoplasmic reticulum. $x 9600$. 


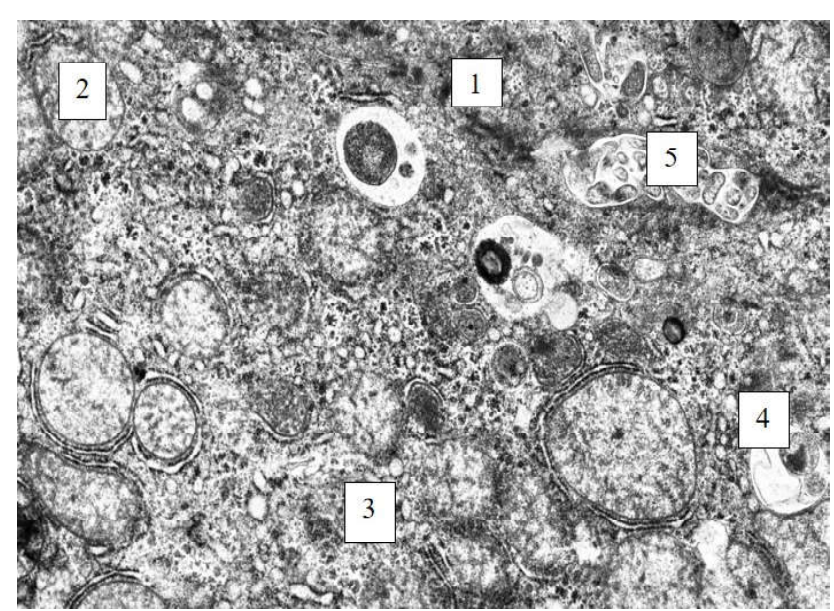

Fig. 2. Electronogram of the liver of a mature rat at HHC: 1 cytoplasm of hepatocytes; 2 - mitochondria; 3 - tubules of the granular endoplasmic reticulum; 4 - autophagosomes; 5 - lumen of the bile capillary. $x 9600$.

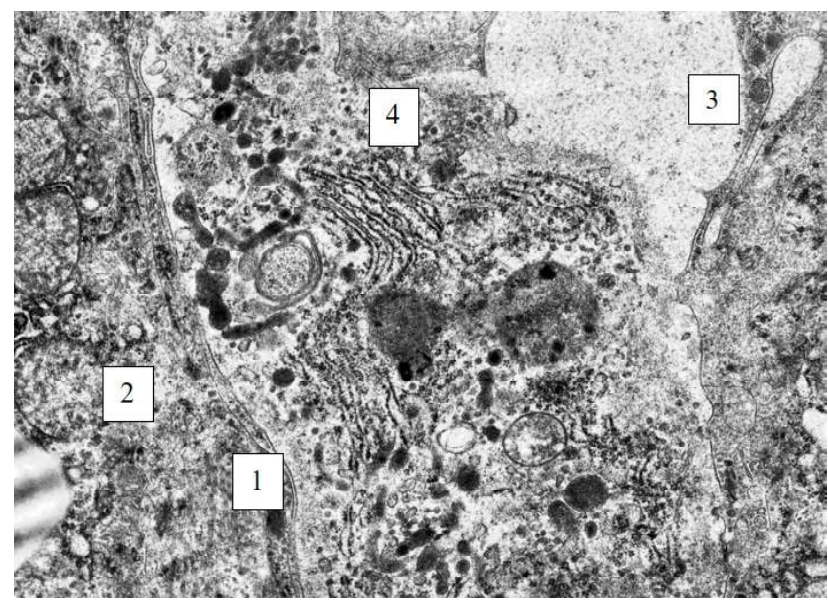

Fig. 3. Electronogram of the liver of a mature rat at HHC: 1 vascular part of the cytoplasm of the hepatocyte; 2 - mitochondria; 3 - cytoplasm of endothelial wall of the sinusoid; 4 - cytoplasm Ito cells. $x 9600$.

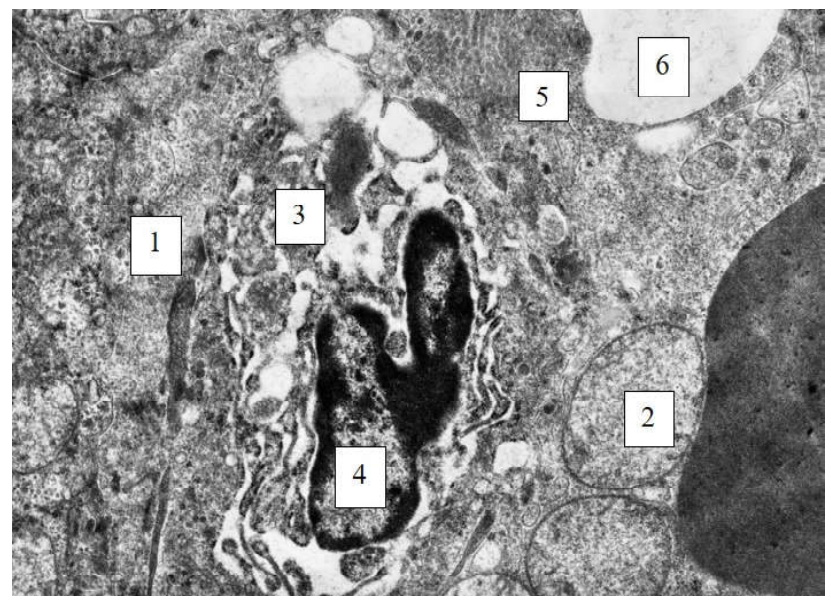

Fig. 4. Electronogram of the liver of a mature rat at HHC: 1 vascular part of the cytoplasm of the hepatocyte; 2 - mitochondria; 3 - Kupffer cell cytoplasm; 4 - Kupffer cell nucleus; 5 - cytoplasm of endothelial sinusoidal wall; 6 - lumen of the sinusoid. x6400. lysosomes were detected. The cytoplasm of Ito cells is enlightened, it contains numerous vacuoles, residual cells, mitochondria with signs of edema. In Ito cells, the content of fat droplets is reduced to 1-3, which are located on opposite poles of cells. This morphological picture manifests the transformation of Ito cells into fibroblasts (Fig. 3).

Perisinusoidal spaces are expanded, they contain processes of hepatocytes, Ito cells, Kupffer cells, as well as fibroblasts, collagen and elastic fibers. The shape of stellate macrophages is changed, their plasmolemma formed numerous processes in contrast to those in intact mature rats. The nuclei of these cells are compacted, chromatin is fragmented. Kupffer cells with enlightened cytoplasm and light nuclei were also detected (Fig. 4).

The lumens of the sinusoids are dilated, the endothelial layer in them is not continuous. Erythrocytes, thrombocytes, leukocytes are defined in capillary gleams. Areas of adhesion of platelets and leukocytes to endothelial plasmolemma were often detected. The latter are swollen, their nuclei protrude into the lumen, and the lumenal surface of the cytoplasm is smoothed. The number of processes in the lumens of the sinusoids is much smaller than in young rats with $\mathrm{HHC}$. Often the thickness of endothelial cells in the walls of the sinusoids is greater than in intact rats. They had few organelles, vacuoles were found in the cytoplasm, and mitochondria were swollen. The nuclei are osmophilic, dark, chromatin in them is marginalized. Around the endothelial cells there is a basement membrane in contrast to intact rats, in which fragments of the latter are located only around the peripheral and contact zone of cells.

\section{Discussion}

The problem of the influence of long-term $\mathrm{HHC}$ on the regularities of morphological and biochemical processes in the liver is studied both by scientists in Ukraine and abroad. Therefore, it is extremely important to compare and summarize the results of the study to establish a complete picture of the features of changes in the structure of the liver at the microscopic and submicroscopic levels under conditions of high concentration of $\mathrm{HC}$.

According to some authors, $\mathrm{HHC}$ leads to inhibition of mitotic activity of hepatocytes due to decreased induction of cyclin D1 and increased expression of p53 and p21Cip1. Electron microscopic examination showed changes in the form of narrowing of the Disse space, shortening and reduction of microvilli on the part of the vascular part of hepatocytes, swelling and disorganization of endothelial cell processes. Characteristic was the increase in phagocytic activity of Kupffer cells, which contained numerous electron-dense polymorphic fine granules and lysosomes. In addition, there is a moderate activation of fibrogenesis, which is manifested by the formation of bundles of collagen fibers in the perisinusoidal space, as well as the presence of Ito cells with a reduced number of lipid inclusions of elongated shape. The latter indicates 
their transformation into myofibroblast-like cells [15].

$\mathrm{HC}$ activates autophagy and exacerbates liver tissue damage by inhibiting the expression of the transmembrane regulator of cystic fibrosis (CFTR). Under normal conditions, the latter inhibits the formation of autophagosomes and associated proteins - BECN1, LC3$\mathrm{II} / \mathrm{I}$ and Atg12. CFTR expression is regulated by the interaction of DNA methyltransferase and histone lysine $\mathrm{N}$ methyltransferase encoded by the $\mathrm{EZH} 2$ gene. These enzymes provide the processes of methylation of DNA and histones, but under the conditions of $\mathrm{HHC}$, their interaction is disrupted, and, consequently, the mechanism of hepatocyte death by autophagy is triggered [19].

When $\mathrm{HC}$ were administered to rats at a dose of $100 \mathrm{mg} / \mathrm{kg}$, plethora of interstitial and central veins in portal areas, as well as sinusoidal capillaries were observed. The process is accompanied by moderate leukocyte infiltration of the portal tracts, and in the central areas of the classical hepatic lobe revealed necrosis of hepatocytes. $23 \%$ of liver cells have signs of microdroplet fatty degeneration. According to the authors, the biochemical basis of the steatogenic action of $\mathrm{HHC}$ is hypomethylation and activation of oxidative stress. The latter manifested itself in the form of increased activity of NADPH oxidase, superoxide dismutase and carbonyl groups of proteins in liver homogenates [14].

The relationship between non-alcoholic fatty liver disease and changes in methionine metabolism, which is manifested by a decrease in the content of methionine in hepatocytes with a simultaneous increase in the level of $\mathrm{HC}$ due to remethylation. The remethylation process proceeds under conditions of normal activity of methionine synthase and betaine-homocysteine methyltransferase. The

\section{References}

[1] Arutiunian, A. V., Pustyhyna, A. V., Myliutyna, Yu. P., Zalozniaia, I. V., \& Kozyna, A. S. (2015). Molecular markers of oxidative stress in offspring with experimental hyperhomocysteinemia. Molecular medicine, (5), 41-46.

[2] Azad, M. A. K., Huang, P., Liu, G., Ren, W., Tekebrh, T., Yan, W., ... \& Yin, Y. (2018). Hyperhomocysteinemia and cardiovascular disease in animal model. Amino Acids, 50(1), 3-9. doi: 10.1007/ s00726-017-2503-5

[3] Dai, H., Wang, W., Tang, X., Chen, R., Chen, Z., Lu, Y., \& Yuan, $H$. (2016). Association between homocysteine and nonalcoholic fatty liver disease in Chinese adults: a cross-sectional study. Nutr J, 15(1), 102. doi: 10.1186/s12937-016-0221-6

[4] Faversani, J. L., Hammerschmidt, T. G., Sitta, A., Deon, M., Wajner, M., \& Vargas, C. R. (2017). Oxidative Stress in Homocysteinuria Due to Cystathione $\beta$-synthase Deficiency: Findings in Patients and in Animal Model. Cell Mol Neurobiol, 37(8), 1477-1485. doi: 10.1007/s10571-017-0478-0

[5] Hirase, T., \& Node, K. (2012). Endothelial dysfunction as a cellular mechanism for vascular failure. Am J Physiol Heart Circ Physiol, 302(3), 499-505. https://doi.org/10.1152/ ajpheart.00325.2011

[6] Horalskyi, L. P., Khomych, V. T., \& Kononskyi, O. I. (2011). Fundamentals of histological technique and morphofunctional research methods in normal and pathology. Zhytomyr: expression of these enzymes at $\mathrm{HHC}$ does not change, but the serine content decreases, which impairs the transfer of methyl groups from methyl tetrahydrofolate. At the optical level, this manifests itself in the form of panacinar macroand microvesicular steatosis, inflammatory changes and fibrosis of liver tissue $[9,13,16]$.

Folic acid deficiency in hepatocytes leads to a violation of the regulation of $\mathrm{HC}$ metabolism, an increase in which is accompanied by a decrease in the concentration of Sadenosylmethionine (SAM). The latter alters cellular lipid metabolism, activates transcription factors in the liver and enhances cholesterol synthesis. The effect of $\mathrm{HHC}$ is also due to the activation of oxidative stress, disruption of $\mathrm{NO}$ synthesis, changes in homeostasis and activation of inflammatory mediators. High concentrations of $\mathrm{HC}$ stimulate the production of collagen in the vessel wall, have a vasoconstrictor effect. HHC activates TNF- $\alpha$, cytokines IL-6, IL-8, increases intracellular levels of superoxidation. These factors ultimately trigger the process of apoptosis of hepatocytes. In addition, this process is accompanied by mitochondrial dysfunction and, as a result, impaired ?oxidation of fatty acids, increased production of free radicals and necrosis [11].

\section{Conclusions}

In adult rats with experimental $\mathrm{HHC}$ ultrastructural changes in hepatocytes, endothelial cells in the walls of sinusoids, Kupffer cells were dystrophic and destructive in nature and were more pronounced than in young rats. The fact that mitochondria have fewer number of cristae and an enlightened matrix indicates their decompensation (depletion). A characteristic feature is the transformation of Ito cells into fibroblasts.

\section{Polissya.}

[7] Hsu, C. C., Cheng, C. H., Hsu, C. L., Lee, W. J., Huang, S. C., \& Huang, Y. C. (2015). Role of vitamin B6 status on antioxidant defenses, glutathione and related enzyme activities in mice with homocysteine-induced oxidative stress. Food Nutr Res, 59: 25702. doi: 10.3402/fnr.v59.25702

[8] Huo, Y., Wu, X., Ding, J., Geng, Y., Qiao, W., Ge, A., ... \& Fan, W. (2018). Vascular Remodeling, Oxidative Stress and Disrupted PPAR Y Exspression in Rats of Long-Term Hyperhomocysteinemia with Metabolic Disturbance. PPAR Res, doi: 10.1155/2018/6738703

[9] Jacobs, R. L., Jiang, H., Kennelly, J. P., Orlicky, D. J., Allen, R. H., Stabler, S. P., ... \& Maclean, K. N. (2017). Cystathione betasynthase deficiency alters hepatic phospholipid and choline metabolism: post-translation repression of phosphatidylethanolamine $\mathrm{N}$-methyltransferase is a consequence rather than a cause of liver injury in homocysteinuria. Mol Genet Metab, 120(4), 325-336. doi: 10.1016/j.ymgme.2017.02.010

[10] Kovalenko, V. M., Andrushko, I. I., \& Talaieva, T. V. (2011). Association of hyperhomocysteinemia with metabolic risk factors in patients with coronary heart disease. Ukrainian Journal of Cardiology, (6), 66-70.

[11] Kychyhyna, O. N., Holubeva, T. I., Troshyna, I. A., \& Romanova, 
N. V. (2015). Pathogenetic significance of hyperhomocysteinemia in non-alcoholic fatty liver disease. Medical science and education of the Urals, 3(38), 177-182.

[12] Lutsiuk, M. B., Zaichko, N. V., Hryhorieva, G. S., Konakhovych, M. A., Artemchuk, M. A., Pentiuk, N. O., \& Postovitenko, K. P. (2013). Hyperhomocysteinemia syndrome: causes, methods of prevention and treatment. Rational pharmacotherapy, 29(4), 55-60.

[13] Melnyk, A. V., \& Zaichko, N. V. (2017). Gender features of the influence of hyperhomocysteinemia on the metabolism of sulfur-containing amino acids and hydrogen sulfide in the liver. Medical and clinical chemistry, 1 (19), 95-101.

[14] Nekrut, D. O. (2016). The effect of hyperhomocysteinemia on the formation of nonalcoholic fatty liver disease in rats. Bulletin of morphology, 22(1), 40-45.

[15] Novohrodskaia, Ya. I., Kravchuk, R. I., Ostrovskaia, O. B., \& Kurbat, M. N. (2019). Morphological changes in the liver of rats with hyperhomocysteinemia. Hepatology and Gastroenterology, 3(1), 93-98.

[16] Pacana, T., Cazanave, S., Verdianelli, A., Patel, V., Min, H. K., Mirshahi, F., ... \& Sanyal, A. S. (2015). Dysregulated Hepatic Methionine Metabolism Drives Homocysteine Elevation in Diet-
Induced Nonalcoholic Fatty Liver Disease. PLoS One, 10(8), e0136822. doi: 10.1371/journal.pone.0136822

[17] Pentiuk, O. O., Lutsiuk, M. B., \& Artemchuk, M. A. (2007). Preclinical studies of hyperhomocysteinemic action of potential drugs. K.: State Pharmacological Center of the Ministry of Health of Ukraine.

[18] Tsybykov, N. N., Tereshkov, P. P., Sepp, A. V., \& Yzmestev, S. V. (2015). The mechanism of hypercoagulation in experimental hyperhomocysteinemia. Thrombosis, hemostasis, rheology, 4(64), 27-30.

[19] Yang, A., Jiao, Y., Yang, S., Deng, M., Yang, X., Mao, C., ... \& Jiang, Y. (2018). Homocysteine activates autophagy by inhibition of CFTR expression via interaction between DNA methylation and H3K27me3 in mouse liver. Cell Death Dis, 92(2), 169-182. doi: 10.1038/s41419-017-0216-Z

[20] Zaichko, N. V., Lutsiuk, M. B., \& Hryhorieva, G. O. (2012). Hyperhomocysteinemia: medical, social and pharmacological aspects. Pharmaceutical courier, 9, 30-35.

[21] Zobova, D. A., \& Kozlov, S. A. (2016). The role of homocysteine in the pathogenesis of certain diseases. Medical sciences, 3(39), 132-144.

\section{ВПЛИВ ГІПЕРГОМОЦИСТЕЇНЕМІЇ НА ЗАКОНОМІРНОСТІ ЕЛЕКТРОННО-МІКРОСКОПІЧНИХ ЗМІН В ПЕЧІНЦІ ЩУРІВ ЗРІЛОГО ВІКУ}

Галаган Ю. В., Маєвський О. Є., Гумінський Ю. Й., Король А. П.

Одним із важливих завдань сучасної науки є пошук біохімічних маркерів, які б здатні були відображати ризики розвитку та характер перебігу різноманітних захворювань, а також спрогнозувати їх можливі наслідки. За останні роки виявлено значну кількість сполук, здатних впливати на особливості біохімічного просрілю організму. Гомоцистеїн - продукт обміну метіоніну, належить до одного з таких маркерів, а наслідки його впливу на структуру та фрункції різних органів активно вивчаються дослідниками сьогодення. Метою дослідження $є$ вивчення закономірностей електронно-мікроскопічних змін структури печінки щурів зрілого віку при гіпергомоцистеїнемії. Експериментальне дослідження проведене на 22 білих нелінійних зрілих щурах-самцях, яких було поділено на групу контролю та дослідну групу. Модель стійкої гіпергомоцистеїнемії створювали шляхом введення щурам дослідної групи тіолактону гомоцистеїну в дозі 200 мг/ка маси тіла інтрагастрально протягом 60 днів. Вивчення ультраструктурних змін в печінці щурів проводили за допомогою електронного мікроскопу ПЕМ125К. У щурів зрілого віку при експериментальній гіпергомоцистеїнемії на ультраструктурному рівні встановлені дистрофрічні та деструктивні зміни в гепатоцитах, ендотеліоцитах в стінках синусоїдів і зірчастих макрофрагоцитах. Дані зміни були більш виражені, ніж у молодих щурів при експериментальній гіпергомоцистеїнемії. Виявлені структурні зміни декомпенсації (виснаження) мітохондрій - менша кількість крист і просвітлений матрикс. На відміну від молодих, у щурів зрілого віку при гіпергомоцистеїнемії в перисинусоїдних просторах виявляли жиронакопичувальні клітини видовженої форми, значну частку цитоплазми займає комплекс Гольджі та цистерни гранулярної ендоплазматичної сітки, що вказувало на синтез білка на експорт. В жиронакопичувальних клітинах зменшений вміст крапель жиру, які розміщені на протилежних полюсах клітин. Така морфологічна картина маніфестує трансформацію жиронакопичувальних клітин у фрібробласти.

Ключові слова: щури зрілого віку, печінка, гіпергомоцистеїнемія, зірчасті макрофраги, жиронакопичувальні клітини.

\section{ВЛИЯНИЕ ГИПЕРГОМОЦИСТЕИНЕМИИ НА ЗАКОНОМЕРНОСТИ ЭЛЕКТРОННО-МИКРОСКОПИЧЕСКИХ ИЗМЕНЕНИЙ В ПЕЧЕНИ КРЫС ЗРЕЛОГО ВОЗРАСТА}

Галаган Ю. В., Маевский А. Е., Гуминский Ю. И., Король А. П.

Одной из важных задач современной науки является поиск биохимических маркеров, которые были бы способны отражать риски развития и характер течения различных заболеваний, а также спрогнозировать их возможные последствия. За последние годы обнаружено значительное количество соединений, способных влиять на особенности биохимического профиля организма. Гомоцистеин - продукт обмена метионина, относится к одному из таких маркеров, а последствия его влияния на структуру и фрункции различных органов активно изучаются исследователями современности. Целью исследования является изучение закономерностей электронно-микроскопических изменений структуры печени крыс зрелого возраста при гипергомоцистеинемии. Экспериментальное исследование проведено на 22 белых нелинейных зрелых крысахсамцах, которые были разделены на группу контроля и исследовательскую группу. Модель устойчивой гипергомоцистеинемии создавали путем введения крысам исследовательской группы тиолактона гомоцистеина в дозе 200 мг/кг массы тела интрагастрально в течении 60 дней. Изучение ультраструктурных изменений в печени крыс проводили с помощью электронного микроскопа ПЭМ-125К. У крыс зрелого возраста при экспериментальной гипергомоцистеинемии на ультраструктурном уровне установлены дистрофические и деструктивные изменения в гепатоцитах, эндотелиоцитах в стенках синусоидов и звездчатых макрофагоцитах. Данные изменения были более выражены, чем у молодых крыс при экспериментальной гипергомоцистеинемии. Выявленные структурные изменения декомпенсации (истощение) митохондрий - меньшее количество крист и просветленный матрикс. В отличие от молодых, у крыс зрелого возраста при гипергомоцистеинемии в перисинусоидных пространствах выявляли жиронакопительные клетки удлиненной формы, 
значительную долю цитоплазмы занимает комплекс Гольджи и цистерны гранулярной эндоплазматической сети, что указывало на синтез белка на экспорт. В жиронакопительных клетках уменьшено содержание капель жира, расположенных на противоположных полюсах клеток. Такая морфологическая картина манифестирует трансформацию жиронакопительных клеток в фибробласты.

Ключевые слова: крысы зрелого возраста, печень, гипергомоцистеинемия, звездчатые макрофраги, жиронакопительные клетки. 